\title{
3-D Liquefaction Potential Analysis of Seabed at Nearshore Area
}

\author{
Chih-Hsin Chang \\ Lien-Kwei Chien \\ Keelung 202, Taiwan., lkchien@mail.ntou.edu.tw \\ Yao-Hsien Chang \\ Master, Department of Harbor and River Engineering, National Taiwan Ocean University.
}

Doctoral Candidate, Department of Harbor and River Engineering, National Taiwan Ocean University, Keelung, Taiwan.

Professor, Department of Harbor and River Engineering, National Taiwan Ocean University, No. 2, Pei-Ning Road,

Follow this and additional works at: https://jmstt.ntou.edu.tw/journal

Part of the Civil and Environmental Engineering Commons

\section{Recommended Citation}

Chang, Chih-Hsin; Chien, Lien-Kwei; and Chang, Yao-Hsien (2004) "3-D Liquefaction Potential Analysis of Seabed at Nearshore Area," Journal of Marine Science and Technology: Vol. 12: Iss. 3, Article 2.

DOI: $10.51400 / 2709-6998.2232$

Available at: https://jmstt.ntou.edu.tw/journal/vol12/iss3/2

This Research Article is brought to you for free and open access by Journal of Marine Science and Technology. It has been accepted for inclusion in Journal of Marine Science and Technology by an authorized editor of Journal of Marine Science and Technology. 


\section{3-D Liquefaction Potential Analysis of Seabed at Nearshore Area}

Acknowledgements

This research was supported by the National Science Council of the Republic of China under Grant No. NSC 91-2211-E-019-013. Grateful appreciation is expressed for this support. 


\title{
3-D LIQUEFACTION POTENTIAL ANALYSIS OF SEABED AT NEARSHORE AREA
}

\author{
Chih-Hsin Chang*, Lien-Kwei Chien**, and Yao-Hsien Chang***
}

Key words: liquefaction potential, seabed, nearshore, wave period, cyclic triaxial test.

\section{ABSTRACT}

In this research, we discussed about the wave induced seabed liquefaction at nearshore based on the viewpoint of marine geotechnical engineering. The behaviors of seabed sand under wave loading were evaluated by experiments carried out in the Chien's cyclic triaxial testing system (type II). Different loading periods, effective confining pressure and relative densities affected the liquefaction resistance of seabed sand that we sampled at northeastern coast in Taiwan. Furthermore, this study proposed the 3-D evaluation method of seabed liquefaction at Yi-Lan nearshore in case that combined the liquefaction resistance of seabed sand and Nearshore Spectral Windwave (NSW) model. The new 3-D method could evaluate the distribution and thickness of wave-induced seabed liquefaction at nearshore area.

\section{INTRODUCTION}

Chien et al. (2003) investigated the erosive of sandy bed caused the coastline receded at northeastern Taiwan. Wave-induced seabed liquefaction is one of the possible reasons for the erosion of the sandy shore. (Bennett and Faris, 1979; Sassa and Sekiguchi, 1999, 2001; Sumer et al., 1999; Hsiao and Huang, 2000)

Typhoon induced water waves propagating in the ocean create a cyclic pressure on the ocean-floor, which may be significant in shallow water and may cause severe damages in coastal zone. This in turn induces stress and pore pressure fields in fluid-filled porous seabed and the pore water pressure would accumulate increasingly until instability occurred such as erosion, liquefaction and shear failure in the seabed. Thus, the evaluation of seabed response under wave action is

Paper Submitted 12/31/03, Accepted 04/08/04. Author for Correspondence: Lien-Kwei Chien. E-mail: lkchien@mail.ntou.edu.tw.

*Doctoral Candidate, Department of Harbor and River Engineering, National Taiwan Ocean University, Keelung, Taiwan.

**Professor, Department of Harbor and River Engineering, National Taiwan Ocean University, No. 2, Pei-Ning Road, Keelung 202, Taiwan. *** Master, Department of Harbor and River Engineering, National Taiwan Ocean University. important for various offshore installations.

Rahman and Jaber (1986) studied the wave-induced instability of seabed. The results showed that a seabed with cohesive soil might suffer from shear failure, leading to slope instability. However, a saturated seabed with non-cohesive sediments could experience liquefaction. Nataraja and Gill (1983) described a method that makes use of standard penetration test (SPT) data, while the approach of Ishihara and Yamazaki (1984) uses the relative density of sand to evaluate liquefaction resistance. However, both methods are similar in principle, in that they compare the wave-induced shear stresses with the values required to cause liquefaction.

Tzang (1998) noted that a lot of suspended sand in test field when soil in liquefied in a study of sand drift behavior on seabed. Sassa and Sekiguchi (1999) investigated the behaviors of wave-induced liquefaction of beds of fine-grained sand under fluid wave trains by using centrifuge modeling. They noted that the waveinduced liquefaction of the sandy beds was of a progressive nature.

Among these, Henkel (1970) may have been the first to identify the water waves play an important role on submarine landslides. In addition, Bjerrum (1973) was the first recognized and analyzed the possibility of wave-induced liquefaction occurring in saturated seabed sediments, in connection with the foundation design for deep-water structures in the North Sea.

The purpose of this study is to establish the behaviors of seabed sand under wave loading by experiments carried out in the Chien's cyclic triaxial testing system (type II). Therefore, this research discusses the influence of important parameters in detail such as different loading periods, effective confining pressures and relative densities. Finally, we assess the stability of the nearshore area by evaluating the wave induced liquefaction potential of seabed sand.

\section{EXPERIMENTAL METHOD}

\section{General description of test apparatus}

The system described here is the Chien's cyclic 
triaxial testing system (type II) that was designed to perform cyclic and static loading to study the liquefaction resistance of large soil specimens, as shown in Fig. 1. Three sizes include $71.12 \mathrm{~mm}, 101.6 \mathrm{~mm}$ and $152.4 \mathrm{~mm}$ in diameter for testable specimens. The corresponding author set the test system (type I) in 1994, and improved in 2002. This system can perform three types of triaxial test, such as static triaxial test in stress control by air pressure or stroke control by stepping motor jack and cyclic triaxial test.

In the Chien's cyclic-triaxial testing system (type II), the computer programmed electronic signal for rate and magnitude of loading is applied to the electropneumatic transducer, which then controls pneumatic amplifiers for the application of loading. The control system was compiled by Visual Basic, and the process of testing was displayed on the monitor at any stage. The user can adjust various parameters such as loading periods, shapes of loading wave and number of loading cycles that you need in this system, as shown in Fig. 2. The storage of test data is limited by the capacity of hard disk.

\section{Test material}

This research sampled the soil at Yi-Lan nearshore seabed, northeastern coasts in Taiwan. The physical properties of test material were listed in Table 1. The soil of northeastern coasts in Taiwan is uniform, fine, black sand and classified as SP according to the Unified Soil Classification System, USCS.

\section{Test simulation}

Cyclic triaxial tests on saturated sand are used in this study to simulate the seafloor soil under wave action, as shown in Fig. 3. Based on small-amplitude wave theory, the wave force is regarded as cyclic stress loading when it forced on the seabed. Under the wave, for example, the soil elements will undergo a kind of

Table 1. The physical properties of soil samples

\begin{tabular}{l|c}
\hline \multicolumn{1}{c|}{ Soils } & $\begin{array}{c}\text { Yi-Lan sand } \\
\text { (Northeastern } \\
\text { Properties }\end{array}$ \\
\hline Maximum dry density $\left(\mathrm{g} / \mathrm{cm}^{3}\right)$ & 1.579 \\
Minimum dry density $\left(\mathrm{g} / \mathrm{cm}^{3}\right)$ & 1.270 \\
Specific gravity & 2.75 \\
$\mathrm{D}_{50}(\mathrm{~mm})$ & 0.302 \\
$\mathrm{D}_{10}(\mathrm{~mm})$ & 0.181 \\
$\mathrm{D}_{30}(\mathrm{~mm})$ & 0.255 \\
$\mathrm{D}_{60}(\mathrm{~mm})$ & 0.335 \\
$\mathrm{Coefficient})$ & 1.851 \\
Coefficient of cuniformature, $\mathrm{Cd}$ & 1.072 \\
\hline
\end{tabular}

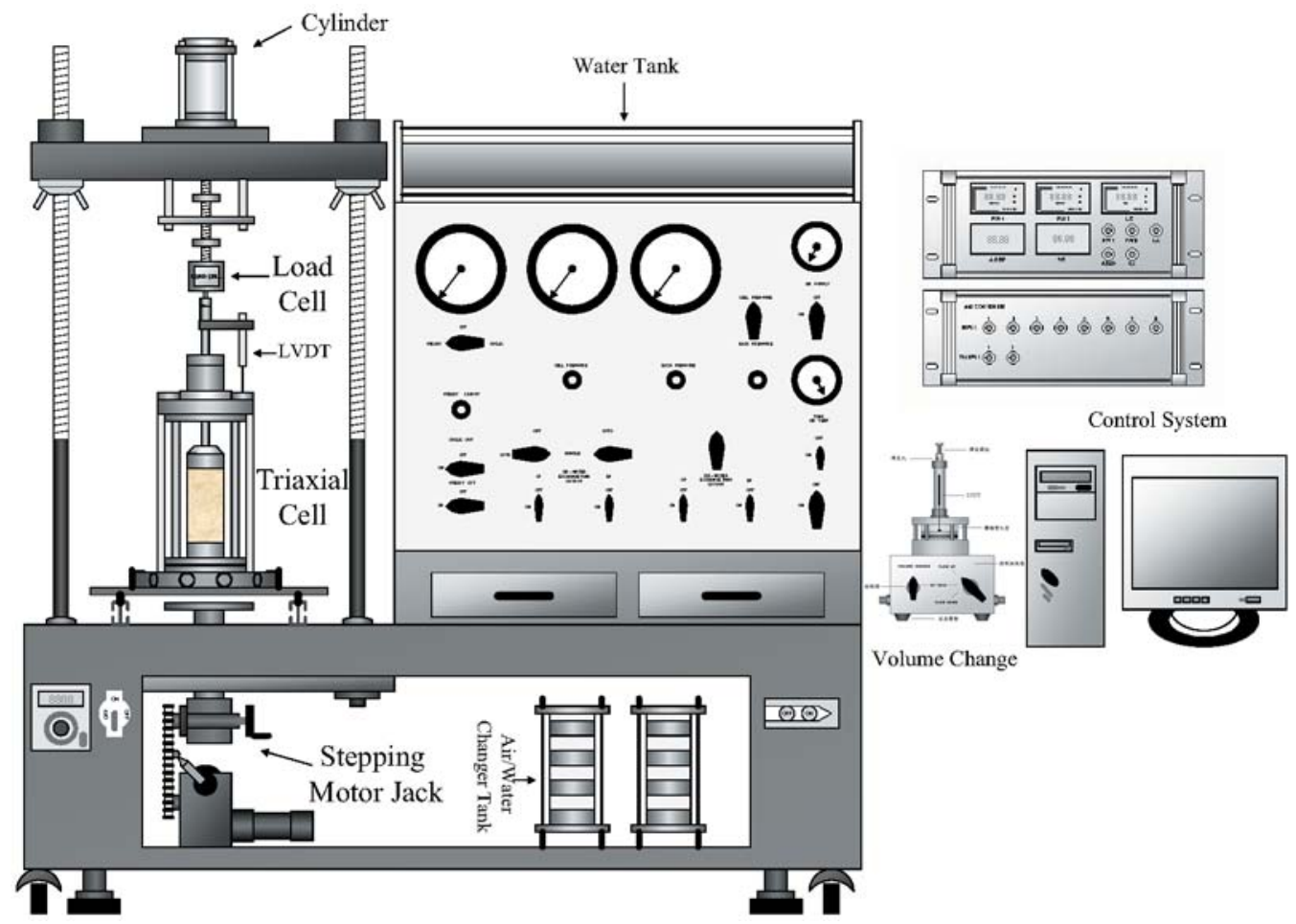

Fig. 1. Sketch of the Chien's cyclic-triaxial testing system (type II) apparatus. 
deviatoric loading, with the major principal stress axis aligned vertically.

According to Madsen derived wave-induced stress in homogeneous seabed, Ishihara and Yamazaki (1984) expressed vertical stress $\left(\sigma_{v}\right)$, horizontal stress $\left(\tau_{h}\right)$ and shear stress $\left(\tau_{v h}\right)$ as follows:

$$
\begin{aligned}
& \sigma_{v}=P_{0}\left(1+\frac{2 \pi z}{L}\right) \cdot e^{\frac{-2 \pi z}{L}} \cdot \cos \left(\frac{2 \pi x}{L}-\frac{2 \pi t}{T}\right) \\
& \sigma_{h}=P_{0}\left(1+\frac{2 \pi z}{L}\right) \cdot e^{\frac{-2 \pi z}{L}} \cdot \cos \left(\frac{2 \pi x}{L}-\frac{2 \pi t}{T}\right) \\
& \tau_{v h}=P_{0} \cdot \frac{2 \pi z}{L} \cdot e^{\frac{-2 \pi z}{L}} \cdot \sin \left(\frac{2 \pi x}{L}-\frac{2 \pi t}{T}\right) \\
& L=\frac{g T^{2}}{2 \pi} \cdot \tan h\left(\frac{2 \pi d}{L}\right)
\end{aligned}
$$

Where $L$ is the wavelength, $g$ is the gravity, $d$ is the water depth, $T$ is the wave period and $P_{0}$ is simple harmonic wave induced wave amplitude that defined as follows:

$$
P_{0}=\rho_{w} \cdot g \cdot \frac{H}{2} \cdot \frac{1}{\cosh (2 \pi d / L)}
$$

Where $H$ is wave height and $\rho_{w}$ is specific gravity of water

According to vertical stress, horizontal stress and shear stress, the difference of maximum and minimum mean principle stress in triaxial test can be expressed as follows:

$$
\frac{\sigma_{1}-\sigma_{3}}{2}=\sqrt{\left(\frac{\sigma_{v}-\sigma_{h}}{2}\right)^{2}+\tau_{v h}^{2}}=P_{0}^{2} \cdot \frac{2 \pi z}{L} \cdot e^{\frac{-2 \pi z}{L}}
$$

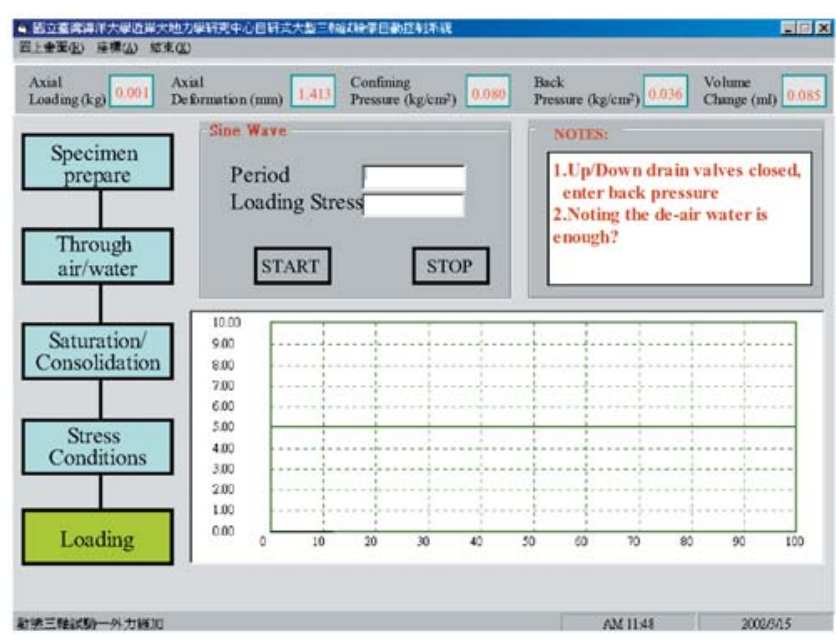

Fig. 2. The control system that compiled by visual basic.

$$
\left(\tau_{v h}\right)_{\max }=\frac{\sigma_{1}-\sigma_{3}}{2}=\left(\frac{\sigma_{v}-\sigma_{h}}{2}\right)_{\max }
$$

\section{Test conditions}

We used the moist tamping method that the soil sample divided into 5 layers to prepare specimens. After the specimen consolidated, a series of liquefaction test evaluated the properties of wave-induced liquefaction behaviors.

To understand the liquefaction resistance of the sand at northeastern coast in Taiwan, specimens were controlled by relative density, $\mathrm{Dr}=35 \%$ and $55 \%$ for loose and moderate seabed sand under different effective confining pressures at $30 \mathrm{kPa}$ and $50 \mathrm{kPa}$ for simulating different seabed soil depths as $3 \mathrm{~m}$ and $5 \mathrm{~m}$ that discussed the characteristics of seabed in detail.

Tsai and Kuo (1994) reported that the characteristic of wave at northeastern Taiwan. The wave height ranges 2-3 m and wave period ranges 8-10-s typically, however wave would be $7.4 \mathrm{~m}$ in height and 12 -s in period of northeastern monsoon in winter. In summer, most wave height less then $1.5 \mathrm{~m}$, wave period ranges from 6 to 8 -s. However, wave height would be $7.15 \mathrm{~m}$ and wave period would be 9 -s during typhoon.

According to in-situ data, the cyclic triaxial test regarded cyclic loading under different periods (as 5, 9, and 12-s) as the mean properties of wave-induced loading in this study. Otherwise, 1 -s period of cyclic loading was also adopted for a comparison.

\section{Definition of seabed liquefaction}

Under the action of severe traveling waves, liquefaction was first induced in the uppermost layer of the sand bed, and then the liquefaction front advanced downward in the course of wave loading. Finally, the entire soil bed was brought into a state of complete

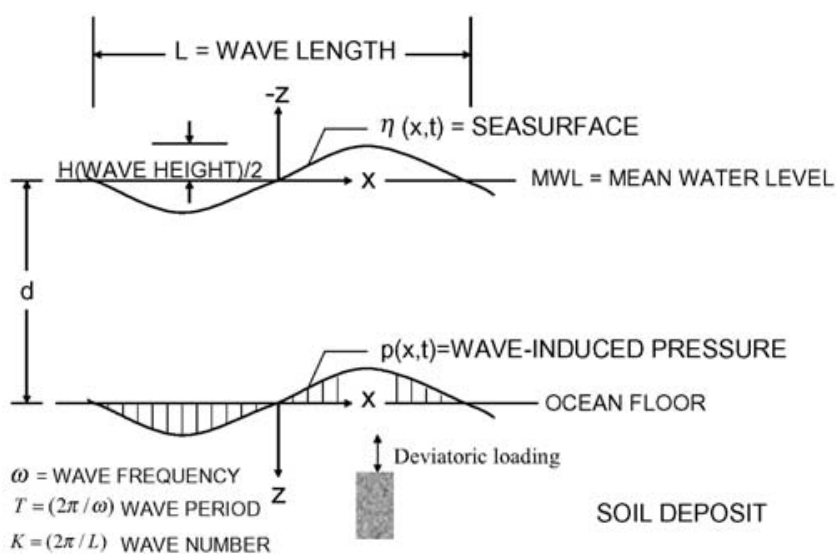

Fig. 3. Soil element of seabed under wave-induced stress. 
liquefaction (Sassa and Sekiguchi, 1999). According to Seed (1979), liquefaction is a term that denotes the condition where a soil will undergo continued deformation at a low stress or without residual resistance. In this study, "initial liquefaction" that liquefaction has taken place at a location when the measured pore water pressure reach the value of initial confining pressure is adopted as the definition for wave-induced seabed liquefaction during cyclic triaxial test.

Generally, the cyclic stress ratio SR illustrated the liquefaction resistance of soil if the state of "initial liquefaction" occurred. This study expressed the cyclic stress ratio $S R$ as follows:

$$
S R=\sigma_{d} / 2 \cdot \sigma_{3}^{\prime}
$$

Where, $\sigma_{d}$ is deviator stress and $\sigma_{3}^{\prime}$ is effective confining pressure.

\section{LIQUEFACTION RESISTANCE OF SEABED SAND}

\section{Effects of cyclic loading period}

The cyclic triaxial testing performed the obvious differences between wave and earthquake loading with different cyclic loading periods. This tests adopted 1-s of loading period for earthquake-induced liquefaction. In general, wave periods range from 4 to 13 -s that several times the period of earthquake. Thus, the first step to study the effects of wave-induced liquefaction on seabed sand in cyclic triaxial system is cyclic loading periods.

\section{(1) Properties of looser seabed sand}

A series of cyclic triaxial test performed the sea-

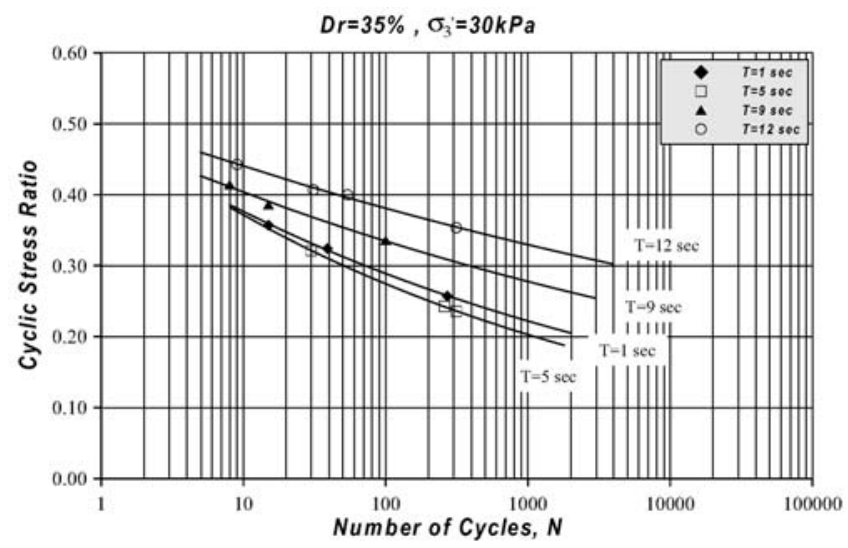

Fig. 4. Effect of wave period on liquefaction resistance strength for case of $\mathrm{Dr}=35 \%$ and $\sigma_{3}=30 \mathrm{kPa}$. bed sand at northeastern coast in Taiwan with $35 \%$ of relative density and different loading periods (as 1, 5, 9 and 12-s). The relationship between liquefaction resistance and number of cycles of seabed sand under different cyclic loading periods with $30 \mathrm{kPa}$ of effective confining pressure is shown in Fig. 4. The liquefaction resistance of seabed sand would increase as wave period increased. The difference of liquefaction resistance between 9 and 12-s loading periods were indistinct but higher than the results of 5-s loading period test. Comparing with the results of 1 -s period loading that represents earthquake, the liquefaction resistance higher than 5 -s period loading a little. Furthermore, the liquefaction results of seabed sand with $50 \mathrm{kPa}$ of confining pressure are shown in Fig. 5. Comparing Fig. 4 and Fig. 5, effects of loading periods under different seabed depths have similar tendency. Moreover, the liquefaction resistance would decrease insignificant as effective confining pressure increased.

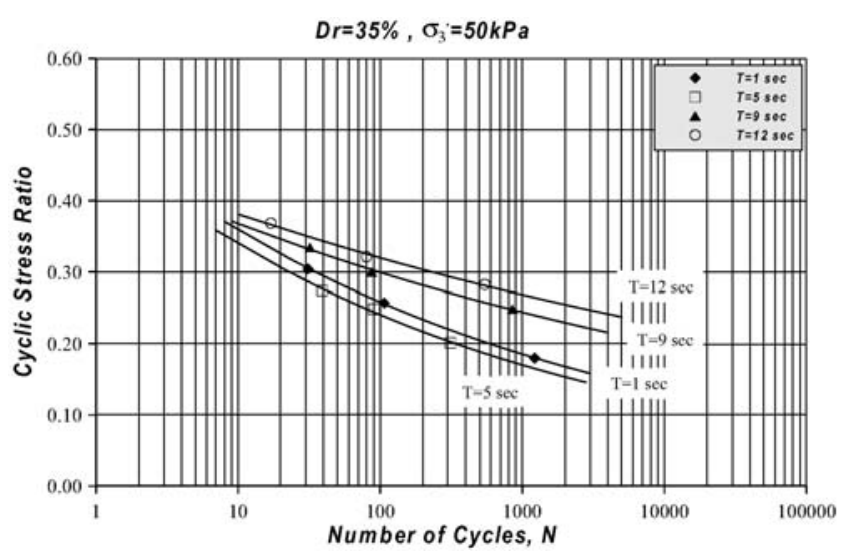

Fig. 5. Effect of wave period on the liquefaction resistance strength for case $D r=35 \%$ and $\sigma_{3}^{\prime}=50 \mathrm{kPa}$.

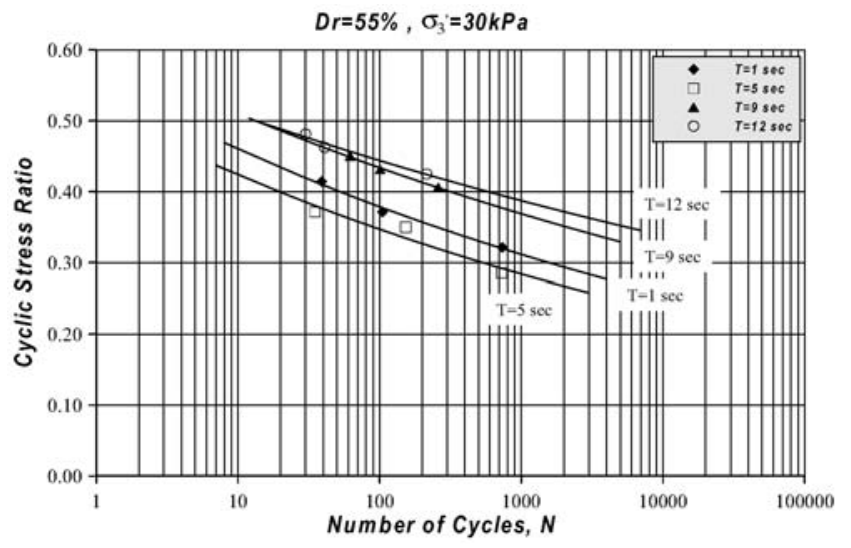

Fig. 6. Effect of wave period on the liquefaction resistance strength for case of $\mathrm{Dr}=55 \%$ and $\sigma_{3}=30 \mathrm{kPa}$. 


\section{(2) Properties of moderately dense seabed sand}

In this section, seabed sand was prepared with $55 \%$ of relative density. The liquefaction resistance of different loading periods with $30 \mathrm{kPa}$ of effective confining pressure is shown in Fig. 6. Under wave loading, the difference of liquefaction resistance between 9 and 12-s loading periods are indistinct but higher than the results of 5-s loading period test. Furthermore, the liquefaction results of seabed sand with $50 \mathrm{kPa}$ of effective confining pressure are shown in Fig. 7, in which the liquefaction resistance would increase as wave period increased. Comparing loose and moderate seabed sand, the loading period effect of liquefaction resistance has the same tendency. Moreover, all of the series testing $\left(D r=35 \%: \sigma_{3}=30,50 \mathrm{kPa} ; \mathrm{Dr}=55 \%\right.$ : $\left.\sigma_{3}^{\prime}=30,50 \mathrm{kPa}\right)$, the difference of liquefaction resistance between 9 and 12-s periods or 1 and 5-s periods were not significant. The results of liquefaction resistance of different depths at 3 and $5 \mathrm{~m}$ would decrease only slightly as effective confining pressure increased. This study agreed well with the experiments of Mulilis et al. (1977).

As revealed by the results of this study, the loading period would have a distinct effect of liquefaction resistance for seabed sand of northeastern coasts in Taiwan. For wave-induced seabed liquefaction analysis, liquefaction resistance of seabed soil should be evaluated with different cyclic loading periods for simulating insitu wave conditions.

Comparing with previous studies, Lee and Fitton (1969) indicated that the liquefaction resistance under high frequency loading was about $10 \%$ lower than the one under low frequency loading. However, Wong et al. (1975) shown just contrary results. Mulilis et al. (1977) considered that, for a frequency between $1 / 30 \mathrm{~Hz}$

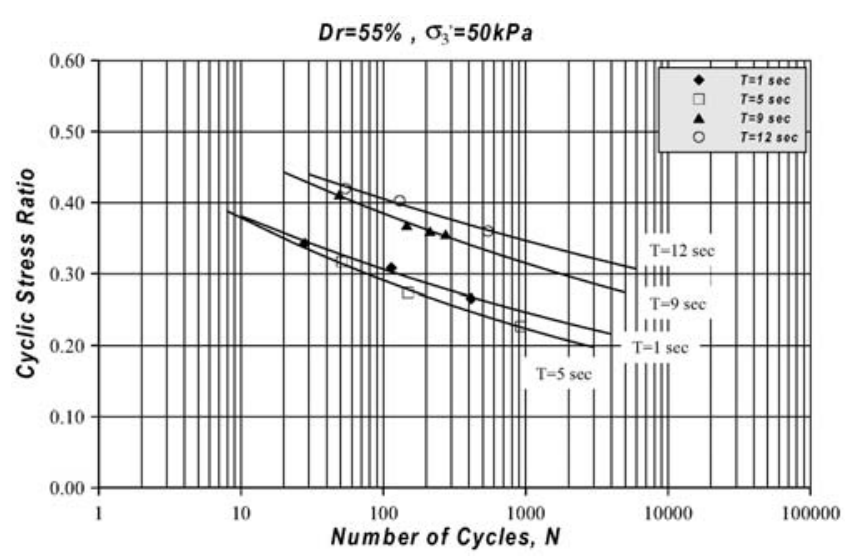

Fig. 7. Effect of wave period on the liquefaction resistance strength for case of $D r=55 \%$ and $\sigma_{3}^{\prime}=50 \mathrm{kPa}$. and $16 \mathrm{~Hz}$, the dynamic strength of soil could neglect the influence of loading frequency. In this study, different wave loading periods influenced the liquefaction resistance of seabed sand. The experimental results provide a clearer relationship between liquefaction resistance of seabed sand and wave loading period. Thus, evaluating the wave-induced liquefaction potential should consider the effects of wave loading period in future.

\section{THE EVALUATION METHOD OF WAVE-INDUCED SEABED LIQUEFACTION}

\section{Simplified evaluation of wave-induced liquefaction}

At least three simplified criterions have been developed to evaluate the possibility of wave-induced liquefaction of granular seabed. All these methods are similar in principle that compared the wave-induced shear stresses with the values required to cause liquefaction. A brief description will be given of each method.

\section{(1) Nataraja and Gill's Analysis (1983) [12]}

This procedure involves the following steps: (1) Selection of design wave data for input into the analysis; (2) Computation of the wave-induced bottom pressure, $p_{0}$ by using Eq (5); (3) Computation of the amplitude of wave-induced shear stresses, $\tau_{v h}$ by using Eq. (9); (4) Estimation of cyclic shear strength from SPT test data. The cyclic shear stress ratio required to cause liquefaction is then calculated by using Eq (11); (5) Finally, the factor of safety is calculated, as a function of depth, as the ratio $\tau_{l} / \tau_{v h}$.

$$
\begin{aligned}
& \tau_{v h} \cong 3.25 \cdot p_{0} z / L \quad(z / L \leq 0.1) \\
& \tau_{l}=0.009 \cdot N_{1} \cdot \sigma_{v}^{\prime}
\end{aligned}
$$

\section{(2) Ishihara and Yamazaki's Analysis (1984) [8]}

This method involves the following steps: (1) Specification of the conditions of the design storm; (2) Evaluation of the cyclic shear strength of the seabed sand, expressed as cyclic stress ratio $\left(\tau / \sigma_{v}^{\prime}\right)_{l}$ to cause liquefaction; (3) If the cyclic shear strength ratio exceeds 0.23 , liquefaction type will not be expected anywhere. Determination the value of related depth $h / L$; (4) For each value of $h / L$ determined, the water depth $h$ and wavelength $L$ can be determined; (5) Calculation the depth factor $z / L$ of liquefaction; (6) The depth $z$ is then the depth to which liquefaction extends. 


\section{(3) Chen and Yang's Analysis (1996) [3]}

Chen and Yang [3] proposed the liquefaction evaluation method based on Ishihara and Yamazaki's analysis [8] and wave data in field. They present a case study of their approach for evaluating liquefaction potential of seabed sand in Kaohsiung nearshore.

\section{Discussion on liquefaction resistance strength of seabed soil}

Nataraja and Gill (1983) reported that the cyclic shear stress ratio (S.R.) decrement is approximately 40$20 \%$ from $N c=10$ to $N c=100$, but the S.R. between the number of cycles $(N c)$ at 100 and 1,000 have no significant differences. Thus, for wave-induced seabed liquefaction problems, Nataraja and Gill (1983) and Ishihara and Yamazaki (1984) suggested that evaluating the liquefaction potential of seabed could adopt the S.R. related number of equivalent stress cycles (Neq) of $N c$ $=100$.

However, this study indicated that liquefaction resistance of seabed sand between $N c$ of 100 and 1,000 has obvious differences under different wave periods as shown in Fig. 4-Fig. 7. Comparing the difference of cyclic shear stress ratio between $N c=100$ and $N c$ $=1,000$, the difference was approximately $20 \%$ under $50 \mathrm{kPa}$ of effective confining pressure and 5-s of wave loading period. This difference still existed no matter loading period is 9 -s or 12 -s. Thus, the number of equivalent stress cycles (Neq) was not suggested at $N c$ $=100$ for evaluating the wave-induced seabed liquefaction in this study.

\section{Liquefaction resistance of different loading periods}

If S.R. of $N c=100$ was adopted for Neq, the liquefaction resistance of seabed would be overestimated. Thus, the liquefaction resistance of seabed sand adopted the S.R. at $N c=1,000$ based on Fig. 4-Fig. 7. The liquefaction resistance of seabed sand would increase about linear as loading period increased. The linear relationship could provide the liquefaction resistance of seabed sand under in-situ wave periods for the analysis of wave-induced seabed liquefaction.

\section{A CASE STUDY OF NORTHEAST NEARSHORE IN TAIWAN}

\section{A summary description of the case study}

The Yi-Lan alluvial plain is located at the mouth of Lan-Yang stream, northeast coast of Taiwan and faces the Pacific Ocean. Beach erosion and reduction by typhoons and artificial constructions is serious problem there in recent years. The $5 \mathrm{~m}$ depth of water near 200$300 \mathrm{~m}$ away from the coastal line, and the $20 \mathrm{~m}$ contour of water depth at 1,500-2,000 m away from the coastal line except north area. The averaged slope gradient of seafloor ranges from $1 / 75$ to $1 / 100$. In this area of case study, "Test Conditions" discussed the wave characteristics and deep wave attacks coast directly. Furthermore, the boring data reported sandy seabed deposited 3-10 m depth of water.

\section{Liquefaction potential analysis at Yi-Lan nearshore area}

The analysis approach of liquefaction potential that based on Ishihara and Yamazaki (1984) method and the liquefaction resistance of seabed were presented as follows:

1. Specification of the conditions of the storm, including the deepwater wave steepness $\delta=H_{0} / L_{0}$, and the wavelength $L_{0}$ or the wave period $T$ shown in Table 2.

2. Evaluation of the cyclic shear strength of seabed deposit, this could be estimated approximately as follows:

(1) According to Fig. 4-Fig. 7, the liquefaction resistance of seabed sand was calculated.

(2) The cyclic stress ratio $\left(\tau_{v h} / \sigma_{v}^{\prime}\right)_{l}$ to cause liquefaction was decided to the related number of cycles equal to 1,000 as $\left(\tau_{v h} / \sigma_{0}^{\prime}\right)_{1000}$. Based on Fig. 4-Fig. 7, the equations between cyclic stress ratio $\left(\tau_{v h} / \sigma_{0}^{\prime}\right)_{1000}$ and relative density shown as follow:

Table 2. Conditions of the design storm

\begin{tabular}{l|cccc}
\hline \multirow{2}{*}{ Conditions } & Wave type & $\begin{array}{c}\text { Wave } \\
\text { period }(\mathrm{s})\end{array}$ & $\begin{array}{c}\text { Wavelength } \\
(\mathrm{m})\end{array}$ & $\begin{array}{c}\text { Wave steepness } \\
\delta=H_{0} / L_{0}\end{array}$ \\
\hline \multirow{2}{*}{ Summer } & Typical & 5 & 39.03 & 0.038 \\
& Typhoon & 9 & 126.47 & 0.057 \\
\hline \multirow{2}{*}{ Winter } & $\begin{array}{c}\text { Typical } \\
\text { Northeastern } \\
\text { monsoon }\end{array}$ & 9 & 126.47 & 0.024 \\
& & 12 & 224.83 & 0.033 \\
\hline
\end{tabular}




$$
\left(\frac{\tau_{v h}}{\sigma_{0}^{\prime}}\right)_{1000}=(0.0010 \cdot \operatorname{Dr}(\%)+0.0261) \cdot\left(3-2 \sin \phi^{\prime}\right)
$$

For the liquefaction resistance curve of cyclic loading period $=1-\mathrm{s}$

$$
\left(\frac{\tau_{v h}}{\sigma_{0}^{\prime}}\right)_{1000}=(0.0009 \cdot \operatorname{Dr}(\%)+0.0255) \cdot\left(3-2 \sin \phi^{\prime}\right)
$$

For the liquefaction resistance curve of cyclic loading period $=5-\mathrm{s}$

$$
\left(\frac{\tau_{v h}}{\sigma_{0}^{\prime}}\right)_{1000}=(0.0012 \cdot \operatorname{Dr}(\%)+0.0400) \cdot\left(3-2 \sin \phi^{\prime}\right)
$$

For the liquefaction resistance curve of cyclic loading period $=9-\mathrm{s}$

$$
\left(\frac{\tau_{v h}}{\sigma_{0}^{\prime}}\right)_{1000}=(0.0013 \cdot \operatorname{Dr}(\%)+0.0439) \cdot\left(3-2 \sin \phi^{\prime}\right)
$$

For the liquefaction resistance curve of cyclic loading period $=12-\mathrm{s}$

(3) The relationship between the cyclic shear stress ratio, $\left(\tau_{v h} / \sigma_{v}^{\prime}\right)_{z}$ to cause liquefaction, the relative density and the friction angle, $\phi^{\prime}$ could be found by using $\sigma_{0}=\left(1+2 K_{0}\right) / 3 \cdot \sigma_{v}^{\prime}$ and $K_{0}=$ $1-\sin \phi^{\prime}$.

(4) This study assumed that the seabed is covered with sand, seabed sand is uniform and have a relative density of $\mathrm{Dr}=35$ or $55 \%$.

(5) Assuming the friction angle is $35^{\circ}$ of loose sand, $40^{\circ}$ of moderate sand based on Das (1998). The cyclic shear stress ratio, $\left(\tau_{v h} / \sigma_{v}^{\prime}\right)_{z}$

Table 3. A list of cyclic shear stress ratio

\begin{tabular}{cccc}
\hline $\begin{array}{c}\text { Cyclic loading } \\
\text { period (s) }\end{array}$ & $\begin{array}{c}\text { Relative } \\
\text { density, } \\
\operatorname{Dr}(\%)\end{array}$ & $\begin{array}{c}\text { Friction } \\
\text { angle, } \\
\phi^{\prime}\left(^{\circ}\right)\end{array}$ & $\left(\frac{\tau_{v h}}{\sigma_{v}^{\prime}}\right)_{Z}$ \\
\hline 1 & 35 & 35 & 0.1060 \\
& 55 & 40 & 0.1410 \\
5 & 35 & 35 & 0.0973 \\
& 55 & 40 & 0.1280 \\
9 & 35 & 35 & 0.1395 \\
& 55 & 40 & 0.1801 \\
12 & 35 & 35 & 0.1534 \\
& 55 & 40 & 0.1981 \\
\hline
\end{tabular}

of different cyclic loading periods effected was shown in Table 3.

3. Determination the value of related depth $h / L$. For each value of $h / L$ determined, the water depth $h$ and wavelength $L$ could be determined. Calculation the depth factor $z / L$ of liquefaction, then the depth $z$ to which liquefaction extended.

4. Application of this approach, Fig. 8 showed the results of the wave-induced liquefaction during typhoon. A summary of the calculations under the wave loading period that contrast with the cyclic loading period $=1-\mathrm{s}$ were shown in Table 4 .

The representative result shown in Fig. 8, under the conditions of wave profile and sand deposit as specified above, the cyclic stress ratio at mud line induced by waves becomes just equal to the cyclic stress ratio at failure when the waves reach to a location with the water depth of $16.1 \mathrm{~m}$ (deposit seabed with $\mathrm{Dr}=$ $35 \%$ ) over the seabed with decreasing depth towards the shore. As the wave travel towards the shore over the seabed with decreasing depth, the wave profile changes thereby increasing the wave steepness, $H / L$, and hence increasing the cyclic stress ratio. Therefore, the maximum liquefaction thickness equal $6.1 \mathrm{~m}$ at water depth is $8.6 \mathrm{~m}$. For deposit seabed with $D r=55 \%$, the initial liquefaction depth at $12 \mathrm{~m}$ with decreasing depth towards the shore. The maximum liquefaction thickness is $2.9 \mathrm{~m}$ of water depth at $3.5 \mathrm{~m}$ is considerably less, as would be expected.

Application the wave periods into cyclic loading periods in the cyclic triaxial test present the liquefaction resistance truly of seabed sand under wave loading. Table 4 shows the extent of liquefaction and influence region in this study concerned (wave period effects) are less than the analysis of those liquefaction resistances established by cyclic loading period was 1-s.

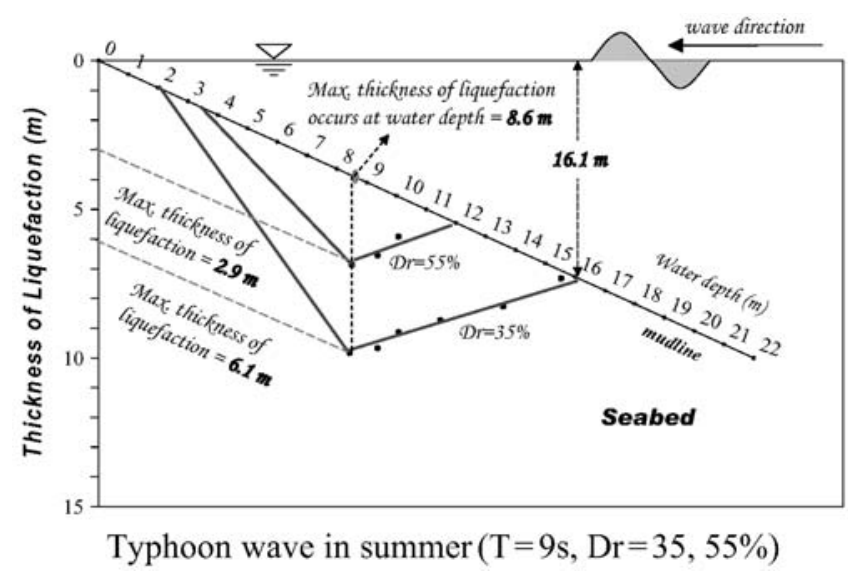

Fig. 8. Case study of wave-induced liquefaction analysis for shoaling seabed deposit. 
Table 4. A summary of the liquefaction analysis under wave loading period and traditional cyclic loading period

\begin{tabular}{|c|c|c|c|c|c|c|c|c|}
\hline Season & Wave types & $\begin{array}{l}\text { Wave } \\
\text { height } \\
\text { (m) } \\
\text { (3) }\end{array}$ & $\begin{array}{l}\text { Wave } \\
\text { period } \\
\text { (s) } \\
\text { (4) }\end{array}$ & $\begin{array}{l}\text { The curve } \\
\text { of liquefaction } \\
\text { resistance } \\
\text { (5) }\end{array}$ & $\begin{array}{l}D r \text { of } \\
\text { sand } \\
(\%) \\
(6)\end{array}$ & $\begin{array}{c}\text { Liquefaction } \\
\text { commences at } \\
\text { water depth (m) } \\
\text { (7) }\end{array}$ & $\begin{array}{l}\text { Maximum } \\
\text { thickness of } \\
\text { liquefaction } \\
\text { layer }(\mathrm{m}) \\
(8)\end{array}$ & $\begin{array}{l}\text { Water } \\
\text { depth of } \\
(8)(\mathrm{m}) \\
(9)\end{array}$ \\
\hline \multirow[t]{8}{*}{ Summer } & Typical & 1.5 & $6-8$ & $5 \mathrm{~s}$ & 35 & 4.7 & 2.4 & 1.8 \\
\hline & & & & & 55 & 3.4 & 1.5 & 1.8 \\
\hline & & & & $1 \mathrm{~s}$ & 35 & 4.4 & 2.1 & 1.8 \\
\hline & & & & & 55 & 3.1 & 1.2 & 1.8 \\
\hline & Typhoon & 7.15 & 9 & $9 \mathrm{~s}$ & 35 & 16.1 & 6.1 & 8.6 \\
\hline & & & & & 55 & 12 & 2.9 & 8.6 \\
\hline & & & & $1 \mathrm{~s}$ & 35 & 21.1 & 9.4 & 8.6 \\
\hline & & & & & 55 & 15.3 & 5.9 & 8.6 \\
\hline \multirow[t]{8}{*}{ Winter } & Typical & $2-3$ & $8-10$ & $9 \mathrm{~s}$ & 35 & 5.4 & 2.3 & 4 \\
\hline & & & & & 55 & & No-liquefaction & \\
\hline & & & & $1 \mathrm{~s}$ & 35 & 7.8 & 4.8 & 4 \\
\hline & & & & & 55 & 5.6 & 2.2 & 4 \\
\hline & Northeastern & 7.4 & 12 & $12 \mathrm{~s}$ & 35 & 13.2 & 4.3 & 8.5 \\
\hline & monsoon & & & & 55 & & No-liquefaction & \\
\hline & & & & $1 \mathrm{~s}$ & 35 & 20 & 10.5 & 8.5 \\
\hline & & & & & 55 & 14.8 & 5.7 & 8.5 \\
\hline
\end{tabular}

\section{Modification of liquefaction potential analysis-3-D liq- uefaction potential analysis}

This research proposed a methodology to predict liquefaction potential based on the cyclic triaxial test of seabed sand, liquefaction evaluation criterion (Ishihara and Yamazaki, 1984) and Nearshore Spectral Windwave (NSW) Model (based on the approach proposed by Holthuijsen et al., 1989). The analysis model can evaluate the site of sand liquefy and the thickness of liquefaction layer, so called three-dimensional liquefaction potential analysis.

The 3-D liquefaction potential analysis of seabed at nearshore area followed the steps that described in above subsection "Liquefaction Potential Analysis at Yi-Lan Nearshore Area". However, some minor modification of this procedure is necessary. The modification involves the following parts: (1). Undersea topography includes bathymetric data for 3-D analysis; (2). Consideration wave periods into cyclic loading periods in cyclic triaxial test, and the cyclic stress ratio, $\left(\tau_{v h} / \sigma_{v}^{\prime}\right)_{z}$ was decided that based on the related number of cycles equal to 1,000; (3). Determination the wave height by using NSW model and bathymetric data. The wave-induced cyclic shear stress ratio, $\left(\tau_{v h} / \sigma_{v}^{\prime}\right)_{0}$ could be determined by using Eq. (15); (4). Calculation the depth of liquefaction layer by using Eq. (16); (5). Then the distribution and thickness of seabed liquefaction

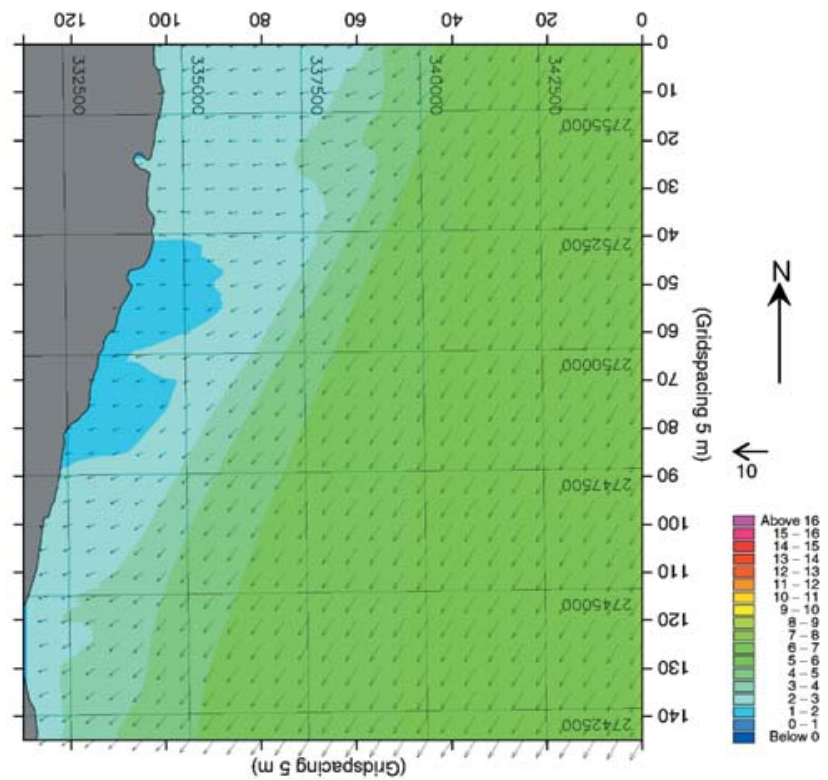

Fig. 9. Wave height distribution at northeastern Taiwan in summer (T $\left.=9 \mathrm{sec}, H_{0}=7.15 \mathrm{~m}, \mathrm{~N}-\mathrm{NE}\right)$.

layer were shown in 3-D diagram by the remodified approach.

$$
\left(\tau_{v h} / \sigma_{v}^{\prime}\right)_{0}=\pi \cdot \frac{\rho_{w}}{\rho^{\prime}} \cdot \frac{H}{L} \cdot \frac{1}{\cos h(2 \pi h / L)}
$$




$$
\frac{\left(\tau_{v h} / \sigma_{v}^{\prime}\right)_{z}}{\left(\tau_{v h} / \sigma_{v}^{\prime}\right)_{0}}=e^{-2 \pi z / L}
$$

According NSW model, the wave height distribution induced by typhoon where, wave height is $7.15 \mathrm{~m}$, wave period is 9 -s in summer are shown in Fig. 9 by inputting the bathymetric data. The wave height is less than the of deepwater wave that due to the friction of seafloor. Deep water wave process in N-NE, the wave height range from 6-7 $\mathrm{m}$ near $4-5 \mathrm{~km}$ away from the coastal line; wave height equal 4-6 $\mathrm{m}$ at 2-3 $\mathrm{km}$ away from coastal line and 2-3 $\mathrm{m}$ in wave height in the coastal zone.

By using of this new proposed 3-D liquefaction potential evaluation method, we evaluated the waveinduced seabed liquefaction under near-shore area. The evaluation of liquefaction potential during typhoon wave in summer shows that liquefaction area would ranges from $12 \mathrm{~m}$ to $3.2 \mathrm{~m}$ in depth of water, and the maximum thickness of liquefaction layer is about $2.7 \mathrm{~m}$ in the medium seabed sand, as shown in Fig. 10 and Fig. 11. It shows that liquefaction develops shallower in the deposit and narrower in the lateral extent. A summary of the remodified 3-D liquefaction analysis listed in Table 5.

Comparing the analytical results between Ishihara and Yamazaki (1984) introduced (Table 4) and the remodified 3-D liquefaction potential evaluation method suggested in this study (Table 5), the extent of liquefaction in this new method is less than the Ishihara and

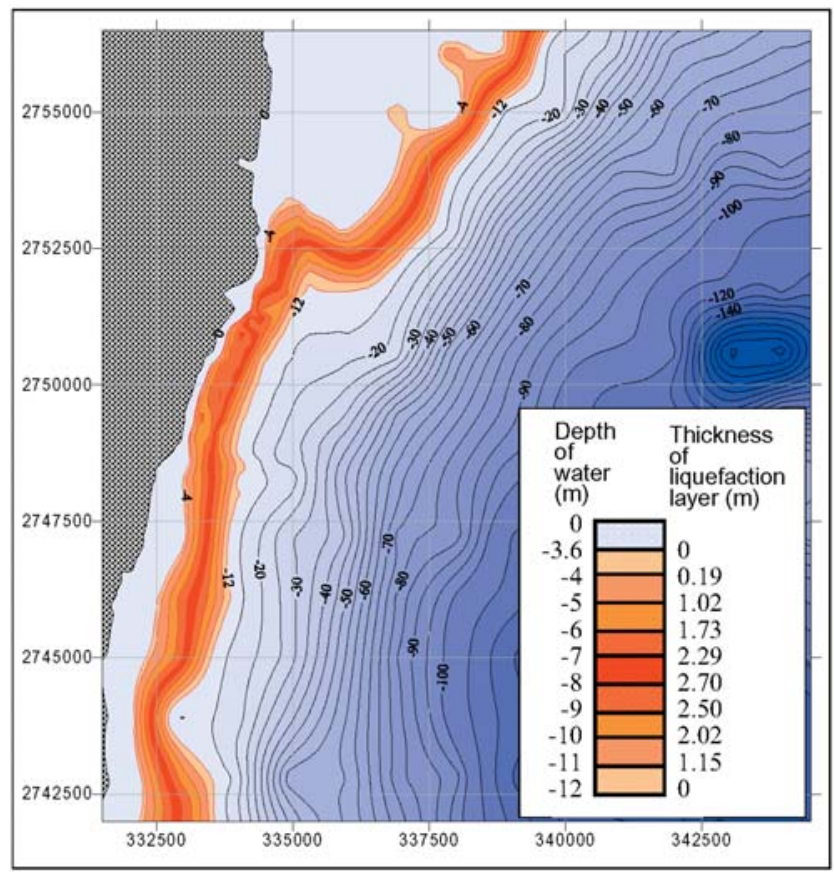

Fig. 10. The evaluation result of 3-D liquefaction potential in Yi-Lan nearshore.
Yamazaki (1984) proposed.

The 3-D liquefaction potential analysis results show that undersea structures such as pipeline or cable in the seabed sand, the position should be installed beneath the seabed surface more than $1.4 \mathrm{~m}$ for stable in summer. However, if the pipeline is embedded at least $2.7 \mathrm{~m}$ below the seabed line, it can be free of liquefaction even under the wave load induced by typhoon.

\section{CONCLUSION}

This research performed the behaviors of Yi-Lan seabed sand under long loading periods for simulating the wave-induced liquefaction phenomenon successfully in the Chien's cyclic-triaxial testing system (type II). The apparatus facility and testing technology are localizable and independent during this researching process.

The experimental results provide a clearer relationship between liquefaction resistance of seabed sand and wave loading period. The liquefaction resistance of Yi-Lan seabed sand would increase as wave period increased. Thus, evaluating the wave-induced liquefaction potential should consider the effects of wave loading period in future. The test results also indicated, the cyclic shear stress ratio between Neq of 100 and 1,000 has obvious differences about $20 \%$. Therefore, the

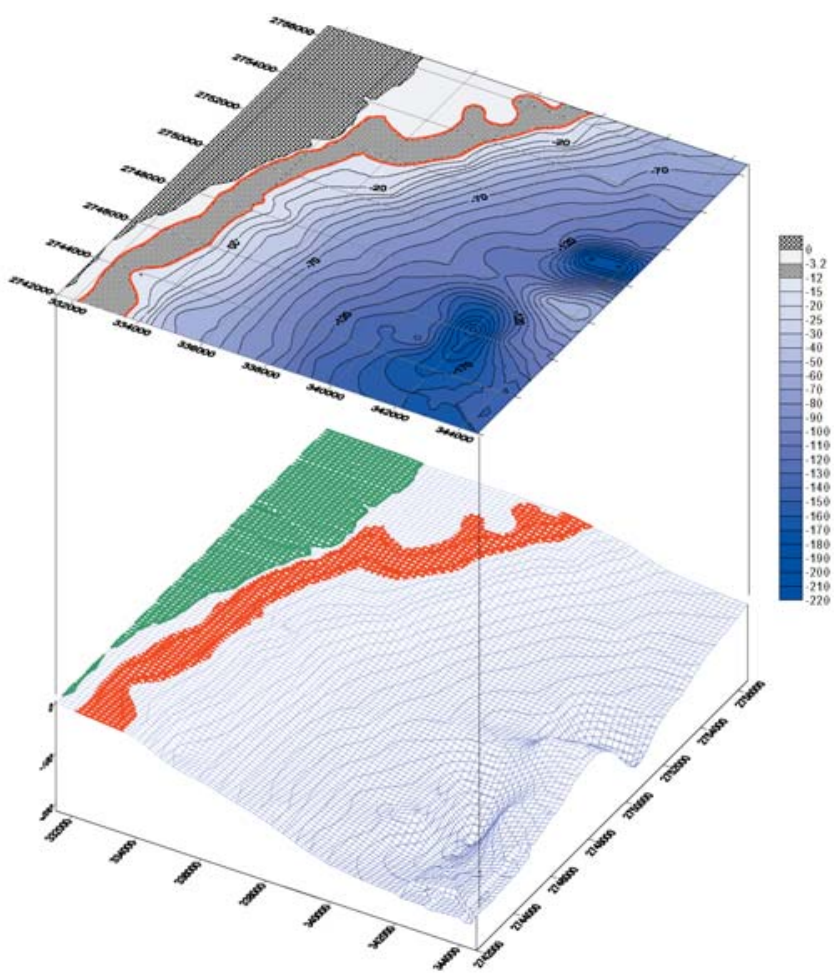

Fig. 11. Example of 3-D liquefaction potential analysis during typhoon wave in summer $(\mathrm{Dr}=55 \%$ of seabed $)$. 
Table 5. A summary of the remodified 3-D liquefaction analysis

\begin{tabular}{|c|c|c|c|c|c|c|c|c|}
\hline Season & Wave types & $\begin{array}{c}\text { Wave } \\
\text { height } \\
\text { (m) } \\
(3)\end{array}$ & $\begin{array}{l}\text { Wave } \\
\text { period } \\
\text { (s) } \\
\text { (4) }\end{array}$ & $\begin{array}{l}\text { Wave height (m) } \\
\text { distribution }\end{array}$ & $\begin{array}{c}\text { Dr of } \\
\text { sand } \\
(\%) \\
(6)\end{array}$ & $\begin{array}{l}\text { Water depth of } \\
\text { liquefaction } \\
\text { are } \\
\text { (7) }\end{array}$ & $\begin{array}{l}\text { Maximum } \\
\text { thickness of } \\
\text { liquefaction } \\
\text { layer }(\mathrm{m}) \\
\text { (8) }\end{array}$ & $\begin{array}{l}\text { Water } \\
\text { depth of } \\
(8)(\mathrm{m}) \\
\text { (9) }\end{array}$ \\
\hline \multirow{2}{*}{ Summer } & Typical & 1.5 & 5 & $\begin{array}{l}1.2-1.4 \text { (north area) } \\
0.4-0.8 \text { (nearshore) }\end{array}$ & $\begin{array}{l}35 \\
55\end{array}$ & $\begin{array}{l}0.2-4.7 \\
0.6-3.4\end{array}$ & $\begin{array}{c}2.2 \\
1.38\end{array}$ & $\begin{array}{l}1.6 \\
1.6\end{array}$ \\
\hline & Typhoon & 7.15 & 9 & $\begin{array}{l}\text { 4-6 (offshore } 2-3 \mathrm{~km} \text { ) } \\
\text { 2-3 (nearshore, Fig. 9) }\end{array}$ & $\begin{array}{l}35 \\
55\end{array}$ & $\begin{array}{l}2-16.1 \\
3.2-12\end{array}$ & $\begin{array}{c}5.37 \\
2.7\end{array}$ & $\begin{array}{l}8.0 \\
8.0\end{array}$ \\
\hline \multirow{2}{*}{ Winter } & Typical & $2-3$ & 9 & 1-2 (nearshore) & $\begin{array}{l}35 \\
55\end{array}$ & $2-5.4$ & $\begin{array}{c}2.42 \\
\text { No-liquefaction }\end{array}$ & 4.0 \\
\hline & $\begin{array}{l}\text { Northeastern } \\
\text { monsoon }\end{array}$ & 7.4 & 12 & $\begin{array}{c}\text { 4-6 (offshore } 2-3 \mathrm{~km} \text { ) } \\
\text { 2-3 (nearshore) }\end{array}$ & $\begin{array}{l}35 \\
55\end{array}$ & $4.6-13.2$ & $\begin{array}{c}3.01 \\
\text { No-liquefaction }\end{array}$ & 7.0 \\
\hline
\end{tabular}

number of equivalent stress cycles (Neq) was not proposed at $N c=100$ for evaluating the wave-induced seabed liquefaction in this study.

Finally, a methodology is proposed to predict liquefaction potential based on the cyclic triaxial test of seabed sand, liquefaction evaluation criterion and Nearshore Spectral Wind-wave (NSW) Model. The analysis model can evaluate the site of sand liquefy and the thickness of liquefaction layer, so called threedimensional liquefaction potential analysis. This research done a case study at Yi-Lan nearshore area base on some assumed conditions and predicted that if the pipeline is embedded at least $2.7 \mathrm{~m}$ below the seabed line, it can be free of liquefaction even under the wave load induced by typhoon. Furthermore, more soil test must be done in detail for planning some major projects.

The reasons of coast erosion would incorporate several kinds of factor but no one factor would be independent. The method of liquefaction analysis was described above does not take into account the effects of pore water pressure dissipation that could take place during a storm period. Therefore, if the liquefaction were to develop only in the shallow depth of deposit, the analysis result would be on a safe side.

\section{ACKNOLEDGEMENT}

This research was supported by the National Science Council of the Republic of China under Grant No. NSC 91-2211-E-019-013. Grateful appreciation is expressed for this support.

\section{REFERENCES}

1. Bennett, R.H. and Faris, J.R., "Ambient and Dynamic Pore Pressures in Fine-grained Subnarine Sediments:
Mississippi," Appl. Ocean Res., Vol. 1, No. 3, pp. 115123 (1979).

2. Bjerrum, J., "Geotechnical Problem Involved in Foundations of Structures in the North Sea," Geotechnique, Vol. 23, No. 3, pp. 319-358 (1973).

3. Chen, J.W. and Yang, C.J., "Liquefaction Potential Evaluation on the Sandy Seabed along the Nearshore of Kaohsiung," J. Chinese Inst. Civil Hydraulic Engin., Vol. 8, No. 1, pp.1-12 (1996). (In Chinese)

4. Chien, L.-K., Chang, C.-H., Hsiao, C.H., Chang, S.C., and Chang, Y.H., "Analysis the Mechanism of Waveinduced Seabed Liquefaction," Proceedings of the 13th International Offshore and Polar Engineering Conference, Honolulu, Hawaii, USA, May 25-30, Volume II, pp. 445-452 (2003).

5. Das, B.M. Principles of Geotechnical Engineering, 4th ed., PWS Publishing Co., Boston, p. 370 (1988).

6. Henkel, D.H., "The Role of Waves in Causing Submarine Landslides," Geotechnique, Vol. 20, No. 1, pp. 7580 (1970).

7. Holthuijsen, L.H., Booij, N., and Herbers, T.H.C., "A Prediction Model for Stationary, Short-crested Waves in Shallow Water with Ambient Currents," Coastal Engin., Vol. 13, pp. 23-54 (1989).

8. Hsiao, D.H. and Hung, L.J., "On the Failure of the Beach Soil of Chi-Chin Coastal Park in Kaohsiung Subjected to Wave Loading," J. Chinese Inst. Civil Hydraulic Engin., Vol. 27, No. 3, pp. 70-84 (2000). (In Chinese)

9. Ishihara, K. and Yamazaki, A., "Analysis of WaveInduced Liquefaction in Sea-bed Deposits of Sand," Soils Foundat., Vol. 24, No. 3, pp. 85-100 (1984).

10. Lee, K.L. and Fitton, J.A., "Factors Affecting the Cyclic Loading Strength of Soil," Vibration Effects Earthquakes Soils Foundat., ASTM STP 450, pp. 71-96 (1969).

11. Mulilis, J.P., Seed, H.B., and Chan, C.K., "Resistance to 
Liquefaction Due to Sustained Pressure," J. Geotech. Engin. Div., ASCE, Vol. 103, No. 7, pp. $793-797$ (1977).

12. Nataraja, M.S. and Gill, H.S., "Ocean Wave-Induced Liquefaction Analysis," J. Geotech. Engin., ASCE, Vol. 109, No. 4, pp. 573-590 (1983).

13. Rahman, M.S. and Jaber, W.Y., “A Simplified Drained Analysis for Wave-Induced Liquefaction in Ocean Floor Sands," Soils Foundat., Vol. 26, No. 1, pp. 57-68 (1986).

14. Sassa, S. and Sekiguchi, H., "Wave-Induced Liquefaction of Beds of Sand in a Centrifuge," Geotechnique, Vol. 49, No. 5. pp. 621-638 (1999).

15. Sassa, S. and Sekiguchi, H., "Analysis of Wave-Induced Liquefaction of Sand Beds," Geotechnique, Vol. 51, No. 2, pp. 115-126 (2001).

16. Seed, H.B., "Soil Liquefaction and Cyclic Mobility Evaluation for Level Ground During Earthquakes," J.
Geotech. Engin. Div., ASCE, Vol. 105, No. 2, pp. 201255 (1979).

17. Sumer, B.M., Fredsoe, J., Christensen, S., and Lind, M.T., "Sinking/Floatation of Pipelines and Other Objects in Liquefied Soil Under Wave," Coastal Engin., Vol. 38, No. 2, pp. 53-90 (1999).

18. Tsai, C.P. and Kuo, C.T., "The Plane of Coast Erosion Studying Yi-Lan Area,” NSC Report, Taipei (1994). (In Chinese)

19. Tzang, S.Y., "Unfluidized Soil Response of a Silty Seabed to Monochromatic Waves," Coastal Engin., Vol. 35, pp. 283-301 (1998).

20. Wong, R.T., Seed, H.B., and Chan, C.K., "Cyclic Loading Liquefaction of Gravelly Soil," J. Soils Mech. Foundat. Div., ASCE, Vol. 101, No. 6, pp. 571-583 (1975). 